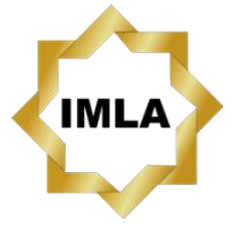

Available online: http://journal.imla.or.id/index.php/arabi

Arabi : Journal of Arabic Studies, 6 (1), 2021, 79-92

DOI: http://dx.doi.org/10.24865/ajas.v6i1.363

\title{
PENGEMBANGAN METODOLOGI PENGAJARAN DAN KOMPETENSI KEPRIBADIAN DOSEN BAHASA ARAB
}

\author{
Faisal Hendra \\ Universitas Al Azhar Indonesia, Jakarta, Indonesia \\ E-mail : faisalhendra2104@gmail.com
}

\begin{abstract}
This article discusses the development of lecturer competencies in using methods and techniques in learning Arabic language proficiency in Indonesian universities. This study uses a descriptive evaluative approach to the data obtained at the Arabic Language and Culture Study Program, Universitas Al Azhar Indonesia (UAI). From the study conducted, it was found that one of the reasons for the not yet maximal ability of students in mastering Arabic language proficiency in Indonesian universities, especially at UAI, was because the lecturers who taught were not maximal in using teaching methodologies and techniques. The technique used is not innovative and tends to be repetitive and boring so that students are not maximally motivated to learn Arabic. Some tips that can be done in instilling a sense of love between lecturers and students in learning and good relations between lecturers and student families can affect the success of the Arabic language learning process that can be implemented.
\end{abstract}

Keywords: development, lecturer competence, development, methodology

\begin{abstract}
Abstrak
Artikel ini mendiskusikan pengembangan kompetensi dosen dalam penggunaan metode dan teknik dalam pembelajaran kemahiran berbahasa Arab di perguruan tinggi Indonesia. Penelitian ini menggunakan pendekatan deskriptif evaluatif terhadap data yang diperoleh di Prodi Bahasa dan Kebudayaan Arab, Universitas Al Azhar Indonesia (UAI). Dari kajian yang dilakukan, didapati bahwa salah satu penyebab belum maksimalnya kemampuan mahasiswa dalam menguasai kemahiran berbahasa Arab di perguruan tinggi Indonesia khususnya di UAI adalah karena dosen yang mengajar belum maksimal dalam mengunakan metodologi dan teknik pengajaran. Teknik yang digunakan tidak inovatif dan cenderung digunakan secara berulang dan membosankan, sehingga mahasiswa tidak termotivasi maksimal dalam belajar bahasa Arab. Beberapa tips yang bisa dilakukan dalam menanamkan rasa cinta antara dosen dan mahasiswa dalam pembelajaran, serta hubungan baik antara dosen dan keluarga mahasiswa yang bisa mempengaruhi keberhasilan proses pembelajaran bahasa Arab yang bisa dilaksanakan.
\end{abstract}

Kata kunci: pengembangan, kompetensi dosen, pengembangan, metodologi 


\section{Pendahuluan}

Kurikulum merupakan bagian terpenting dalam proses pendidikan karena merupakan salah satu alat untuk mencapai tujuan pendidikan, dan juga kurikulum digunakan sebagai pedoman dalam pelaksanaan proses belajar mengajar di setiap tingkat satuan pendidikan. Kurikulum dirancang dan dikembangkan secara terus-menerus sesuai dengan kebutuhan dan perkembangan zaman, ini bertujuan tidak lain untuk membuat proses pendidikan berjalan dan berhasil secara efektif. Sebab sesuai dengan definisinya, kurikulum akan menjadi panduan dalam pelaksanaan pendidikan, tanpa kurikulum dipastikan proses pendidikan akan berjalan tidak terkendali, baik dari sisi perencanaan, proses maupun hasil pendidikan yang ingin dicapai.

Kata "Kurikulum" memiliki berbagai macam makna sebagaimana yang dirumuskan oleh para ahli di bidang pengembangan kurikulum. Makna maupun definisi kurikulum tersebut berbeda antara satu dengan yang lainnya, sesuai dengan titik berat inti dan menurut pandangan dari ahli yang bersangkutan.

Sebagaimana yang dijelaskan Webster's Third New International Distionery, kata kurikulum berasal dari kata curere dalam bahasa latin currerre yang berarti: berlari cepat, tergesa-gesa, menjalani. Kata Currerre dikatabendakan menjadi curriculum yang berarti: 1) lari cepat, pacuan balapan, berkereta, berkuda, berkaki; 2) perjalanan, suatu pengalaman, tanda berhenti; 3) lapangan perlombaan, gelanggang, jalan.

Mengambil makna yang terkandung dari kata tersebut di atas, secara istilah dapat diartikan bahwa kurikulum dalam pendidikan adalah sejumlah mata pelajaran yang harus ditempuh atau diselesaikan oleh pembelajar untuk memperoleh pengakuan akhir yang bersangkutan telah selesai menjalai pendidikan dalam satu tingkat pendidikan yang biasanya ditandai dengan pemberian sertifikat atau ijazah. Dari devenisi di atas didapati bahwa kurikulum sebagai program pendidikan setidaknya meliputi: (1) Kumpulan mata pelajaran atau organisasi pengetahuan yang akan dipelajari. (2) Pengalaman belajar atau kegiatan belajar yang dilakukan. (3) Program belajar untuk pembelajar yang akan dilaksanakan. (4) Hasil akhir proses belajar mengajar yang diharapakan dapat diperoleh. Dengan bahasa yang sederhana dapat disimpulkan bahwa kuriklum adalah jangka waktu pendidikan yang harus ditempuh oleh mahasiswa dengan berbagai aktivitas pendidikan yang dilakukan dan bertujuan untuk memperoleh ilmu pengetahuan, yang dibuktikan dengan sertifikat atau ijazah yang diterima.

Pakar pendidikan berbeda pendapat dalam mengelompokkan unsur yang ada dalam kurikulum, sebagian besar berpendapat unsur kurikulum itu ada empat bagian besar (Ahmad Muradi: 2021:13) yaitu: komponen tujuan, komponen isi, komponen metode atau strategi pencapaian tujuan dan komponen evaluasi. Sebagai suatu sistem yang ada dalam pendidikan setiap komponen harus saling berkaitan satu sama lainnya.

Di sisi lain penulis lebih sepakat dengan yang menyatakan bahwa unsur kurikulum itu bukan empat, akan tetapi lima, merujuk kepada apa yang disampaikan oleh (Zaid Barakah: 45), yang mengatakan bahwa unsur kurikulum terdiri dari lima komponen: komponen tujuan, komponen bahan ajar atau isi, komponen metodologi pengajaran yang didalamnya memuat strategi, komponen alat bantu at au media pengajaran, serta komponen evaluasi, sebagaimana penjelasan berikut ini:

1. Tujuan pengajaran, adalah tujuan atau sasaran yang ingin dicapai dalam kurikulum, yang sudah ditetapkan untuk dicapai pada satu jenjang pendidikan yang akan dilaksanakan.

2. Bahan ajar atau isi, adalah bahan atau buku ajar yang digunakan dan menjadi rujukan dalam pembelajaran untuk mencapai tujuan pembelajara yang akan dilaksanakan.

3. Metode pengajaran, adalah cara mengajar seorang dosen dalam mengajar yang dituangkan kedalam bentuk teknik yang beragam sesuai dengan kebutuhan bahan ajar itu diajarkan. 
4. Media pengajaran/alat bantu. Media pengajaran adalah alat bantu yang dipergunakan sebagai penunjang dalam proses penyampaian materi yang akan disampaikan kepada anak didik. Pelajaran yang didukung dengan menggunakan alat bantu yang tepat akan menjadikan pembelajaran menjadi tepat sasaran dan menambah konsentrasi anak didik di dalam memperhatikan dan mendalami materi yang diajarkan.

5. Evaluasi, adalah sebuah proses yang dilakukan seorang pengajar dalam menilai dan menganalisis apakah bahan materi yang disampaikan kepada murid sudah dikuasai dengan baik atau belum. Evaluasi ini tidak dilakukan hanya dalam bentuk ujian, akan tetapi bisa dilakukan dalam bentuk evaluasi harian, mingguan, bulanan, semesteran dan lain-lain mengawal tercapainya tujuan pembelajaran yang akan dilaksanakan.

Tulisan ini membahas salah satu dari lima unsur yang ada dalam kurikulum pembelajaran bahasa Arab, yaitu pengembangan kompetensi dosen dalam mengajar bahasa Arab, ketika menggunakan satu metode dan beberapa teknik dalam mengajar turunan dari metode yang dipilih. Pemikiran ini muncul setelah melihat realita yang ada di perguruan tinggi Indonesia secara umum, bahwa syarat untuk menjadi seorang dosen di perguruan tinggi Indonesia tidaklah begitu sulit, merujuk kepada isi Undang-undang No.14 tahun 2005, yang menjelaskan tentang kualifikasi akademik, kompetensi dan sertifikasi yang harus dimiliki oleh seseorang yang memilih dosen sebagai profesi. Yang dimaksud dengan kualifikasi akademik menurut: Susanti, dkk (2020:3), adalah tingkat pendidikan minimal yang harus dimiliki seseorang pengajar yang dibuktikan dengan ijazah dan/atau sertifikat keahlian yang relevan sesuai ketentuan perundang-undangan yang berlaku. Adapun kompetensi menurut: Muradi (2016:3) dari Spencer dalam Hamzah (2014: 62), adalah karakteristik yang menonjol dari seorang individu yang berhubungandengan kinerja efektif dan atau superior dalam suatu pekerjaan atau situasi. Terakhir apa yang disebut dengan sertifikasi, menurut Wibawa, dkk (2019: 3) adalah proses pemberian sertifikat pendidik kepada dosen di perguruan tinggi. Ternyata kompetensi yang tertuang dalam undang-undang itu masih bersifat umum, yang menyangkut kemampuan pedagogis, kemampanan pengetahuan yang dimiliki, serta perilaku dosen dalam mengelola kelas. Tentu saja, itu belum mencerminkan kapasitas keilmuan dosen di bidang yang ia geluti. Artinya, seorang dosen pada bidang tertentu, yang memiliki ijazah Magister, dan sudah memperleh sertifikat sebagai seorang pendidik, baik dosen yang berada di bawah Kementrian Pendidikan Tinggi (Kemdikti) ataupun yang ada di bawah Kementrian Pendidikan Agama (Kemenag), belum dapat dipastikan memiliki kompetensi akademik yang memadai sesuai bidang ilmunya. Kata "memadai" memang bersifat relatif; karena itulah diperlukan standarisasi kompetensi akademik sesuai dengan bidang ilmu masing-masing terutama sekali dalam menguasai kompetensi keilmuan dan penggunaan metodologi serta teknik mengajar dalam pembelajaran yang dia laksanakan.

Secara umum kita ketahui, bahwa dosen di Indonesia sudah memiliki apa yang disyaratkan dalam undang-undang tersebut di atas. Namun, secara lebih spesifik, berdasarkan kenyataan di lapangan, banyak dosen yang sudah memenuhi kualifikasi akademik yang disyaratkan, akan tetapi belum memiliki kompetensi yang cukup dalam bidang metodologi pembelajaran, walaupun pada saat yang sama mereka sudah mendapatkan sertifikasi sebagai dosen dari pemerintah. Artinya, seperangkat pengetahuan dan keterampilan yang dimiliki oleh dosen pada bidang tertentu belum mencapai taraf yang ideal dalam pembelajaran. Pernyataan ini mengisyaratkan: pertama, dosen sudah memiliki kompetensi pada bidang ilmu yang dipelajari. Akan tetapi, masih belum maksimal atau ideal, sehingga belum sesuai dengan standar yang seharusnya dikuasai dalam menjalankan sebuah pembelajaran; kedua, sertifikat yang dimiliki belum bisa mengukur tingkat keilmuan dosen yang bersangkutan dalam penguasaan metodologi dalam pembelajaran. Penilaian untuk mendapatkan sertifikasi pendidik ini tidak berbasis penguasaan yang bersangkutan dalam mengajar di mata kuliah yang dibebankan kepada 
yang bersangkutan, khususnya bagi dosen yang akan mengajar kemahiran berbahasa Arab di perguruan tinggi Indonesia.

Ada sebuah fakta yang mengisyaratkan kompetensi keilmuan dan kompetensi metodologis dosen bahasa Arab yang mengajar bahasa Arab di Indonesia belum sesuai dengan standar yang ideal dalam proses pembelajaran yang dilaksanakan. Setiap tahun, Universitas Umm Al-Qura di Mekkah, Saudi Arabia, menyelenggarakan pelatihan pengajaran Bahasa Arab bagi dosen dan guru Bahasa Arab asal Indonesia dan beberapa negara Afrika. Sudah lebih dari 12 tahun penulis termasuk salah seorang yang diberikan kepercayaan oleh Universitas Umm Al-Qura, Mekkah, Saudi Arabia untuk menyeleksi para dosen calon peserta pelatihan dari seluruh Indonesia yang mengajar bahasa Arab di pesantren dan perguruan tinggi Indonesia. Dalam proses seleksi itu, diberlakukanlah semacam tes tulisan dan lisan melaui telepon bagi seluruh calon peserta yang mendaftar, yang berasal dari berbagai provinsi yang ada di Indonesia. Sebagai acuan awal untuk mengukur kemampuan bahasa Arab mereka; yang memiliki kualitas bahasa Arab yang baik selanjutnya akan direkomendasikan untuk mengikuti pelatihan dimaksud di Universitas Umm al-Qura, Saudi Arabia. Setelah berlangsung pelatihan, kami dari tim seleksi mendapatkan masukan dari dari penganggung jawab program dan tim pengajar di Universitas Umm al-Qura, bahwa kompetensi keilmuan bahasa Arab para dosen yang ikut pelatihan serta penguasaan mereka dalam bidang metodologi pengajaran bahasa Arab, masih perlu untuk di tingkatkan. Informasi ini tentunya belum dapat dikatakan simpulan yang representatif dan general untuk seluruh dosen pengajar Bahasa Arab di PT Indonesia, akan tetapi dapat menjadi sebuah sinyal untuk mengkaji dan mengevaluasi kompetensi keilmuan dosen dan kompetensi metodologis mereka dalam mengajar Bahasa Arab.

\section{Metode Penelitian}

Penelitian ini merupakan kombinasi dari penelitian pustaka (library research) dan penelitian lapangan (field research) dengan metode kualitatif deksriptif dengan menjadikan Universitas Al Azhar Indonesia sebagai lokasi penelitian. Data primer diperoleh melalui observasi, wawancara dan dokumentasi, sedangkan data sekunder diperoleh dari buku, jurnal dan sumber lain yang dianggap relevan dengan penelitian. Dalam penelitian ini digambarkan berbagai ide pengembangan kompetensi dosen bahasa Arab di Universitas Al Azhar Indonesia. Untuk mendapatkan data yang diperlukan dalam penelitian ini, penulis menggunakan teknik pengumpulan data dengan cara: pertama, wawancara. Kedua, melakukan observasi pada proses pengembangan kompetensi dosen. Ketiga, pengumpulan dokumentasi. Adapun dokumentasi yang dikumpulkan berupa foto kegiatan, referensi, ppt dan bahan yang digunakan dalam pengembangan kompetensi dosen bahasa Arab. Teknik analisis data yang digunakan mulai dari reduksi data, display data dan verification (penarikan kesimpulan). Untuk uji keabsahan data dilakukan dengan teknik triangulasi.

\section{Pembahasan \\ Standar Kompetensi}

Standar Kompetensi dosen bahasa Arab pada perguruan tinggi ini dikembangkan secara utuh dari empat kompetensi utama, yaitu kompetensi pedagogik, kepribadian, kebahasaan, sosial dan profesional. Kompetensi tersebut diintegrasikan dalam kinerja dosen bahasa Arab pada perguruan tinggi. Standar kompetensi dosen Bahasa arab pada perguruan tinggi mencangkup kompetensi inti dosen yang dikembangkan menjadi kompetensi sebagai berikut:

Vol. 6 No. $1 \mid 82-92$

Copyright (C) 2021 | ARABI | p-ISSN 2548-6616 | e-ISSN 2548-6624 
Arabi : Journal of Arabic Studies

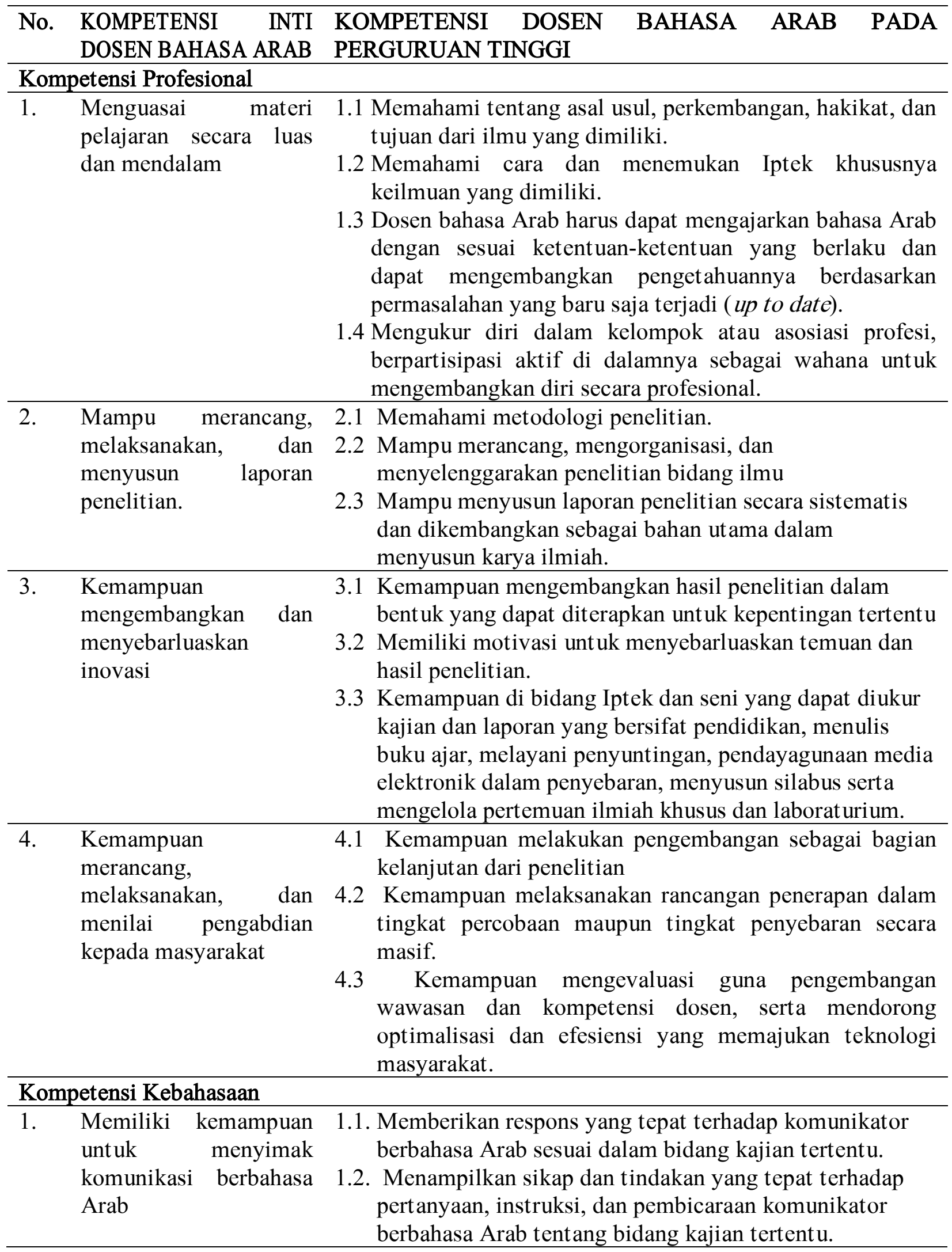


Arabi : Journal of Arabic Studies

\begin{tabular}{|c|c|c|}
\hline No. & $\begin{array}{lr}\text { KOMPETENSI INTI } \\
\text { DOSEN BAHASA ARAB }\end{array}$ & $\begin{array}{llll}\text { KOMPETENSI DOSEN } & \text { BAHASA } & \text { ARAB } & \text { PA } \\
\text { PERGURUAN TINGGI } & & & \\
\end{array}$ \\
\hline 2. & $\begin{array}{lr}\text { Memiliki } & \text { kemampuan } \\
\text { berbicara } & \text { dalam } \\
\text { komunikasi } & \text { aktif } \\
\text { berbahasa Arab } & \end{array}$ & $\begin{array}{l}\text { 2.1. Mempresentasikan substansi salah satu bidang kajian } \\
\text { dalam bahasa Arab. } \\
\text { 2.2. Melaksanakan kegiatan belajar mengajar menggunakan } \\
\text { bahasa Arab secara aktif. }\end{array}$ \\
\hline 3. & $\begin{array}{l}\text { Memiliki kemampuan } \\
\text { membaca karya ilmiah } \\
\text { klasik dan modern } \\
\text { dalam bahasa Arab }\end{array}$ & $\begin{array}{l}\text { 3.1. Memberikan interpretasi dan kesimpulan yang tepat } \\
\text { terhadap karya ilmiah klasik dan modern dalam bahasa } \\
\text { Arab sesuai dengan bidang kajian tertentu. } \\
\text { 3.2. Menjelaskan substansi karya ilmiah yang dibacanya } \\
\text { dengan menggunakan bahasa Arab. }\end{array}$ \\
\hline 4. & $\begin{array}{lr}\text { Memiliki kemampuan } \\
\text { menulis karya ilmiah } \\
\text { tentang } & \text { substansi } \\
\text { kajian } & \text { tertentu } \\
\text { menggunakan } & \text { bahasa } \\
\text { Arab } & \\
\end{array}$ & $\begin{array}{l}\text { 4.1. Menulis karya ilmiah yang dipublikasikan di tingkat } \\
\text { nasional ataupun internasional tentang substansi bidang } \\
\text { kajian tertentu dengan menggunakan bahasa Arab. } \\
\text { 4.2. Membuat laporan penelitian dengan menggunakan } \\
\text { bahasa Arab. }\end{array}$ \\
\hline
\end{tabular}

\section{Pendekatan, Metode dan Teknik Pembelajaran}

Setidaknya ada tiga istilah yang harus kita pahami pengertiannya dalam pembelajaran bahasa Arab agar bisa digunakan secara tepat, ketiga istilah ini adalah, pendekatan, metode dan teknik pembelajaran. Edward Anthony (1963) dalam Effendy (2012: 8) mengatakan bahwa pendekatan adalah seperangkat asumsi yang berkenaan dengan hakikat bahasa dan belajar mengajar bahasa. Sedangkan metode secara terminologis berarti cara atau jalan, dan logos yang berarti ilmu. Sedangkan scara semantik, metodologi berarti ilmu pengetahuan yang mempelajari tentang cara-cara atau jalan yang ditempuh untuk mencapai suatu tujuan dengan hasil yang efektif dan efisien (Hermawan, 2011:35). Sementara secara makna disampaikan oleh Iskandar Wassid dan Sunendar (2011:56), yang mengatakan bahwa metode adalah cara kerja yang sistematis untuk memudahkan pelaksanaan berbagai kegiatan pembelajaran untuk mencapai tujuan yang diinginkan atau ditentukan. Sementara Sutikno (2014:33) menyatakan bahwa "metode" secara harfiah berarti "cara", metode adalah suatu cara atau prosedur yang digunakan untuk mencapai tujuan tertentu. Sementara Hamalik (2003:57) dalam bukunya mengatakan bahwa metode adalah cara atau seperangkat cara, jalan dan teknik yang digunakan oleh pendidik dalam proses pembelajaran agar peserta didik dapat mencapaitujuan pembelajaran atau kompetensi tertentu yang dirumuskan dalam silabus mata pelajaran.

Dari empat pengertian di atas dapat disimpulkan oleh penulis bahwa metode adalah cara yang digunakan untuk mendapatkan hasil yang diinginkan dalam proses pembelajaran yang dilaksanakan, yang terdiri dari tahapan dan langkah-langkah yang dilakukan untuk mencapai tujuan pembelajaran.

Sementara untuk metode pembelajaran Wina Sanjaya (2016:147) dalam bukunya menyatakan bahwa metode pembelajaran adalah cara yang digunakan untuk mengimplementasikan rencana yang sudah disusun dalam kegiatan nyata agar tujuan yang telah disusun tercapai secara optimal. Sedangkan Abdurrahman (2014:42) mengatakan bahwa metode pembelajaran diartikan sebagai cara atau pola yang khas dalam memanfaatkan berbagai prinsip dasar pendidikan serta berbagai teknik dan sumber daya terkait lainnya agar terjadi proses pembelajaran pada diri peserta didik. Definisi sejenis juga disampaikan oleh Abu Ahmadi (2015:52) yang mengatakan bahwa metode pembelajaran adalah teknik yang dikuasai pendidik atau guru untuk menyajikan materi pelajaran kepada peserta didik di kelas, baik secara individu maupun kelompok agar materi pelajaran dapat diserap, dipahami dan dimanfaatkan oleh peserta didik dengan baik.

Vol. 6 No. $1 \mid 84-92$

Copyright @ 2021 | ARABI | p-ISSN 2548-6616 | e-ISSN 2548-6624 
Dalam metode pembelajaran bahasa Arab maupun bahasa asing lainnya, banyak sekali metode yang bisa diterapkan dalam proses belajar-mengajar. Secara umum ada enam metode yang sering menjadi rujukan dalam pembelajaran bahasa Arab di Indonesia, kenam metode ini sebagaimana disampaikan oleh Effendy (2012:41) dalam bukunya, Metodologi Pembelajaran Bahasa Arab, yaitu: Metode gramatika-terjemah atau Thañqah al-Qawāid wa Tarjamah; Metode langsung atau athThañqah al-Mubāsyirah; Metode membaca atau Thañqah al-Qirā'ah; Metode audiolingual atau athThañqah al-Sam'iyah al-Syafahiyah; Metode komunikatif atau Thañqah al-Ittishāliyah; dan Metode Eklektik atau ath-Thaniquh al-Intiqāiyah.

Adapun turunan dari metode yang digunakan dalam pembelajaran kita kenal dengan istilah teknik pembelajaran. Teknik menurut Arinis Ilyas (2018:11) diartikan pelaksanaan secara operasional suatu metode dalam proses belajar dan mengajar. Teknik dipilih sebagai cara yang dilakukan oleh pengajar dalam mengimplementasikan suatu metode pembelajaran. Sebagaimana yang disampaikan oleh (2012:8) bahwa teknik adalah kegiatan spesifik yang diimplementasikan dalam kelas selaras dengan metode dan pendekatan pembelajaran yang telah dipilih.

Selanjutnya penulis akan fokus kepada pengembangan metode dan teknik dalam pengajaran kemahiran berbahasa Arab yang digunakan dalam pengajaran bahasa Arab di perguruan tinggi Indonesia sebagai kajian utama yang akan disampaikan dalam artikel ini.

\section{Pengembangan Metodologi Pengajaran Dosen dalam Mengajar Kemahiran Berbahasa Arab}

Bicara tentang metodologi yang digunakan oleh dosen dalam mengajar bahasa Arab di perguruan tinggi Indonesia, secara umum sudah menggunakan metode yang dianggap tepat menurut penilaian penulis, di mana selain menggunakan enam metode yang ada dalam pembelajaran bahasa Arab diperguruan tinggi mereka masing-masing sesuai yang disampaikan Effendy (2012:41). Bahkan dalam realisasinya cukup banyak para dosen yang sudah mengembangkan metode yang dipilih untuk mengajar kemahiran berbahasa Arab dengan menggunakan metode lain selain enam metode di atas.

Akan tetapi, ketika bicara tentang hasil yang diperoleh dengan menggunakan metodologi yang ada dan dikaitkan dengan kemampuan mahasiswa menguasai kemahiran berbahasa, didapatkan data bahwa kemampuan mahasiswa dalam menguasai kemahiran berahasa Arab belum maksimal. Dari hasil observasi yang dilakukan, didapati data, sebagai contoh, mahasiswa yang belajar di Prodi Bahasa dan Kebudayaan Arab, Universitas Al Azhar Indonesia, tempat penulis mengajar kemahiran berbicara dan termasuk di beberapa PT lainnya. Kemampuan mahasiswa yang diajar belum merata dan belum mencapai tingkat kemahiran yang diharapkan yang seharusnya mereka kuasai, walaupun dalam hitungan tahun mereka sudah kuliah di semester tinggi dan sudah selesai mengambil mata kuliah kemahiran berbahasa tingkat lanjut.

Di antara penyebab belum tercapainya standar ini adalah, di samping kembali kepada hasil usaha masing-masing mahasiswa, penulis melihat bahwa dosen ketika mengajar mahasiswa dengan metodologi yang dipilih belum dibarengi dengan teknik mengajar yang maksimal dan tepat, para dosen belum banyak berinovasi dalam menggunakan teknik mengajar sebagai turunan dari metode yang dipilih, walaupun secara teori, metode yang digunakan oleh dosen sudah sesuai karakter kemahiran berbahasa yang mereka ajarkan (Wardoyo, 2015).

Selanjutnya penulis menawarkan beberapa teori dan aktivitas yang bisa dilakukan oleh dosen pengajar bahasa Arab di perguruan tinggi Indonesia yang bisa dimasukan ke dalam pokok pembahasan utama dari penulisan artikel ini, yaitu pengembangan teknik mengajar kemahiran berbahasa Arab di perguruan tinggi Indonesia, yang dibagi ke dalam: 
Arabi : Journal of Arabic Studies

\section{Sifat Dosen dalam Pembelajaran Bahasa Arab}

Sebagai bagian dari usaha untuk meningkatkan mutu pembelajaran kemahiran berbahasa Arab yang bisa dilakukan oleh dosen, dan masuk ke dalam kontens pengembangan metode dan teknik pembelajaran adalah para dosen harus memiliki sifat yang ideal sebagai seorang dosen, diantara sifat ideal yang dimaksud adalah:

1. Memiliki tujuan yang jelas: Dosen bahasa Arab yang sukses adalah dosen ketika bekerja atau mengajar memiliki tujuan yang jelas dalam pekerjaan yang ditekuninya, untuk menjaga agar tujuan pembelajaran yang direncanakan tercapai dia harus berusaha semaksimal mungkin mengawal apa yang ingin dicapai dalam bentuk komunikasi dua arah antara dia dengan mahasiswanya dan membangun komunikasi yang terbuka antara dia dengan mahasiswa yang dia ajar.

2. Selalu memiliki semangat positif: Seorang dosen bahasa Arab yang sukses dapat dilihat dari semangat positif yang tercermin dari interaksi yang dilakukan di dalam kelas yang dia jalani bersama mahasiswa yang dia ajar, dan dia bisa menyampaikan ilmu dengan baik kepada mahasiswa, dan mahasiswa dengan cepat bisa memahaminya, serta seluruh sikap positif yang dia miliki tergambar dari seluruh aktivitas yang dia lakukan di dalam kampus tempat dia melakukan proses pembelajaran.

3. Tidak menunggu ungkapan terima kasih dari orang lain: Dosen bahasa Arab yang sukses adalah yang bekerja dengan cinta, tulus, dan ikhlas dengan hati nurani yang sadar, dan tidak berharap sama sekali pujian ataupun ucapan terima kasih dari orang lain, walupun untuk sesuatu yang positif. Selalu merasa bangga dalam hatinya ketika dia mendapati mahasiswa yang dia ajar dapat menguasai ilmu yang diajarkan.

4. Dosen bahasa Arab yang sukses dalam pembelajaran memiliki sifat, selalu berharap untuk kesuksesan mahasiswanya: Dia percaya pada kecerdasan yang dimiliki mahasiswanya dan yakin kalau mahasiswanya mampu mengapai kesuksesan mereka dalam hidup dan pembelajaran bahasa Arab yang akan dijalani, dia selalu memberikan motivasi kepada mahasiswanya untuk selalu mencapai nilai tertinggi dari seluruh ujian dan kuliah yang dipelajari, sesuai dengan tujuan dan harapan masing-masing mahasiswa.

5. Pembaharuan: Dosen bahasa Arab yang sukses adalah dosen yang selalu berusaha melahirkan suatu yang baru, berinovasi dalam melakukan aktivitas mengajar yang dilaksanakan, baik dalam menggunakan metode pembelajaran, teknik mengajar, interaksi dengan mahasiswa dan hal-hal baru lainnya untuk mengantarkan mahasiswa ke tingkat keilmuan yang ingin dicapai dalam pembelajaran.

6. Memiliki rasa humor: Seorang dosen bahasa Arab yang sukses menghindari untuk berurusan dengan mahasiswa yang dia ajar serta rekan kerja dengan keseriusan yang berlebihan, dan dia selalu berusaha untuk membarengi keseriusannya dalam mengajar dengan sedikit humor dan canda, termasuk ketika mengajar di kelas dibarengi dengan sedikit humor dalam menyampaikan materi yang ingin diajarkan kepada anak didiknya, sehingga pembelajaran yang dilaksanakan di dalam kelas tidak terasa kaku dan tegang.

7. Mendorong dan memotivasi mahasiswa: Seorang dosen bahasa Arab yang sukses selalu mencoba untuk mendorong siswanya dan memotivasi mereka untuk mendapatkan keilmuan dan nilai bagus dalam seluruh ujian yang dilaksanakan, dan selalu memotivasi mahasiswa untuk melakukan apapun cara positif untuk meningkatkan kompetensi keilmuan mereka agar menjadi lebih baik.

8. Mendengarkan mahasiswa: Seorang dosen bahasa Arab yang sukses, adalah dosen yang mau mendengarkan sesuatu yang baru yang disampaikan oleh mahasiswanya, baik yang berkaitan dengan keilmuan yang dipelajari atupun hal lain yang berhubungan dengan pembelajaran yang

Vol. 6 No. $1 \mid 86-92$

Copyright (C) 2021 | ARABI | p-ISSN 2548-6616 | e-ISSN 2548-6624 
dilaksanakan di kampus, walaupun kadangkala apa yang disampaikan oleh mahasiswa bukan sesuatu yang ada korelasinya dengan pembahasan yang sedang dipelari

9. Netralitas: Seorang dosen bahasa Arab yang sukses berkomitmen pada netralitas dalam profesi yang dia tekuni, merupakan satu kepuasan bagi dia kalau dia bisa mengajar untuk semua mahasiswa, bukan hanya sekelompok mahasiswa tertentu. Tidak membedakan antara satu mahasiswa dengan mahasiswa lainnya, semua digiring untuk berhasil menguasai keilmuan yang dipelajari. Dari sisi mahasiswapun diakui bahwa dosen yang bersangkutan adalah dosen yang netral dan jika kalaupun terjadi perbedaan di dalam kelas dia bisa bersikap sebagai orang tua yang bisa menjadi penengah dari perbedaan yang terjadi antara mahasiswa yang satu dengan mahasiswa lainnya.

10. Interaksi yang baik antara dia dengan mahasiswa: Seorang dosen bahasa Arab yang sukses adalah dosen yang rindu dan selalu ingin berinteraksi dengan mahasiswa yang diajar dan merasa aman dan nyaman saat mereka belajar bersama dan sebaliknya diapun merasa nyaman ketika belajar bersama para mahasiswa yang dia ajar.

\section{Keahlian yang Harus Dimiliki Dosen Bahasa Arab}

Untuk tercapainya tujuan pembelajaran yang ingin dicapai oleh dosen dalam mengajar kemahiran berbicara bahasa Arab, ada beberapa keahlian yang perlu dimiliki oleh dosen Bahasa Arab, di antaranya keahlian ini sebagai berikut (Bakhru, 2017; Supartha, 2020):

1. Persiapan pelajaran lebih awal: Dosen bahasa Arab yang ideal harus mempersiapkan dirinya dengan persiapan yang maksimal sebelum masuk ke dalam ruang kelas. Persiapan maksimal ini menjadi keharusan baik dalam mempersiapkan bahan ajar yang akan dipelajari, metode dan teknik mengajar yang akan digunakan serta penggunaan alat bantu yang akan membantu dia dalam proses pembelajaran yang akan dilaksanakan, agar ketika proses pembelajaran berlangsung, dosen tidak jatuh ke dalam kesalahan dalam penggunaan metode, kesalahan bahan, kesalahan teknik mengajar dan lain sebagainya.

Persiapan mengajar ini harus menjadi fokus para dosen bahasa Arab, karena cukup banyak pengajar yang lebih memilih mengajar sebagai kegiatan rutinitas apalagi bahan ajar yang sama pernah diajarkan pada semester ataupun tahun sebelumnya. Pengulangan mengajar untuk mata kuliah yang sama menjadikan dosen merasa sudah siap menghadapi apa yang akan terjadi di kelas. Kadang kala jika muncul hal baru yang belum pernah muncul sebelumnya maka akan kelihatan dimata para mahasiswa kalau dosen yang bersangkutan tidak menguasai bahan ajar dengan baik dan ini akan menjadi masalah tersendiri bagi dosen yang bersangkutan di mata mahasiswa.

2. Mempersiapkan mental mahasiswa: Mempersiapkan mental mahasiswa sebelum hadir di ruang kelas menjadi satu keharusan bagi seorang dosen bahasa Arab, agar para mahasiswa datang ke kelas bukan hanya sekedar hadir, akan tetapi hadir dengan persiapan yang maksimal. Dia tahu apa bahan yang akan dipelajari hari ini, dia tahu bagaimana cara dosen yang akan mengajarkan bahasa Arab kepada dia hari ini dengan bentuk-bentuk teknik dan bentuk tugas yang sudah dan akan diberikan, dia tahu kalau dosen yang mengajar dia memiliki karakter khusus yang tidak bisa disamakan dengan dosen yang lain, yang pada akhirnya semua itu akan mengantarkan mahasiwa untuk bisa menguasai ilmu yang dipelajari dengan dosen tersebut lebih mudah dan tepat waktu.

3. Memperhatikan pekerjaan rumah mahasiswa: Dosen bahasa Arab yang ideal adalah dosen yang maksimal dalam membaca dan mengoreksi pekerjaan rumah yang diberikan kepada mahasiswanya. Tugas bahasa Arab yang diberikan jika sudah dikerjakan oleh mahasiswa, dibaca dan dikoreksi serta dikembalikan kepada mahasiswa untuk diperbaiki kembali oleh mahasiswa 
yang bersangkutan. Mengoreksi pekerjaan rumah mahasiswa dan mengembalikannya kepada mereka menurut pendapat penulis perlu menjadi satu hal yang sangat penting bagi pengajar bahasa Arab di perguruan tinggi mahasiswa, dan kadang ini sering terabaikan oleh dosen. Jika kecendrungan dosen tidak mengoreksi tugas dan tidak mengembalikannya kepada mahasiswa diketahui oleh mahasiswa, maka akan timbul sikap apriori mahasiswa dan cendrung mengerjakan tugas secara asal, karena mereka tau kalau tugas yang diberikan dosen tidak dikoreksi dan hanya sebatas tugas yang harus dikerjakan tetapi bukan sebagai alat yang maksimal untuk membantu proses pembelajaran yang dilaksanakan.

4. Memiliki keterampilan dalam menggunakan alat bantu atau media pembelajaran: Dosen yang mengajar mahasiswa yang kita kenal dengan generasi milenial harus memperhatikan metode baru, yang muncul di sistem pendidikan Indonesia saat ini dengan menggunakan berbagai media atau alat bantu yang untuk para mahasiswa sudah familiar dan belum tentu familiar dimata dosen pengajar kemahiran berbahasa Arab di perguruan tinggi Indonesia. Keberadaan media baru yang muncul ini harus disikapi sebagai sesuatu yang harus dimasuki dan bukan sesuatu yang akan dijauhi, karena suka atau tidak, media tersebut untuk mahasiswa yang akan kita ajar, mereka sudah terbiasa dengan keberadaannya. Kitalah para pengajar yang harus mau meningkatkan kompetensi kita untuk bisa menggunakan media tersebut dalam proses pembelajaran bahasa Arab yang akan kita laksanakan. Apalagi jika media baru tersebut berbasis teknologi yang saat ini sangat familiar di generasi anak milenial yang kita ajar.

5. Mendorong mahasiswa untuk aktif: Dosen bahasa Arab dalam kelas harus berperan sebagai fasilitator dalam pembelajaran, bukan menjadikan dirinya sebagai satu-satunya sumber dalam pembelajaran yang dilaksanakan. Salah satu peran fasilitator yang benar adalah mendorong mahasiswa untuk aktif dalam mengelola suasana pembelajaran yang dilaksanakan didalam kelas. Dengan menciptakan suasana kelas yang lebih aktif akan meningkatkan kompetensi mahasiswa untuk mau memberi bukan saja hanya menerima ilmu yang diberikan. Suasana akademik yang terciptapun akan berbeda jika hanya menjadikan dosen sebagai satu-satunya sumber dalam pembelajaran Bahasa Arab yang akan dilaksanakan.

6. Merencanakan proses pembelajaran yang akan dilaksankan di dalam kelas: Dosen bahasa Arab di PT Indonesia harus merencanakan proses pembelajaran yang akan dilaksanakan ketika berinteraksi dengan mahasiswa di dalam kelas. Perencanaan ini tidak saja meliputi persiapan dalam bahan ajar, tetapi juga menyeluruh terkait dengan metode, teknik, media dan teknik evaluasi yang digunakan oleh para dosen dalam mengajar bahasa Arab di kelas yang dia ajar untuk mengasah kemampuan mahasiswa dalam pembelajaran kemahiran bahasa Arab yang dipelajari dan mapu mengantarkan mahasiswa untuk menggunakan bahasa Arab yang dipelajari tersebut dalam keseharian mereka di kampus.

7. Mengembalikan hasil tugas dan ujian yang sudah dikerjakan mahasiswa: Ini menjadi satu keterampilan dasar yang harus dimiliki oleh setiap dosen bahasa Arab untuk memberikan dan mengembangkan kepercayaannya kepada mahasiswa yang dia ajar dan begitu juga sebaliknya, dan diusahakan mengoreksi dan mengembalikan tugas atau ujian yang diberikan kepada mahasiswa secepat mungkin terhitung dari waktu tugas atau ujian itu dilaksanakan. Jika waktu pengembalian ujian dan tugas itu terlalu lama, mahasiswa yang bersangkutan akan merasa tidak terlalu butuh karena kegiatannya sudah berlalu beberapa hari, maka perlu pengondisian waktu khusus untuk membahas tugas dan ujian ini bersama mahasiswa.

8. Fleksibilitas: Dosen yang ideal harus berusaha semaksimal mungkin bersikap fleksibel dan tidak kaku ketika berinteraksi dengan mahasiswa yang dia ajar dikelas ataupun diluar kelas, dan membuka pintu dialog dan diskusi dengan para mahasiswa yang diajar dalam suasana yang penuh interaksi positif.

Vol. 6 No. $1 \mid 88-92$

Copyright (C) 2021 | ARABI | p-ISSN 2548-6616 | e-ISSN 2548-6624 


\section{Hubungan Baik Antara Dosen dan Mahasiswa dalam Proses Pembelajaran}

Dalam mendukung proses pembelajaran bahasa Arab bisa berjalan dengan baik, ada beberapa tips yang bisa dilakukan oleh dosen agar proses pembelajaran bisa lebih tepat sasaran. Di antara tips yang bisa dilakukan adalah sebagai berikut:

1. Dosen harus memiliki reputasi yang baik di mata mahasiswa yang diajar dan bisa berperan sebagai ayah atau orangtua yang peduli kepada peningkatan kemampuan mahasiswa yang diajar dan berusaha maksimal untuk mengantarkan mahasiswa menguasai bahasa Arab yang dipelajari dengan baik sebagai bekal bagi mahasiswa untuk mencapai kesuksesan mereka di masa yang akan datang.

2. Dosen harus memperlakukan mahasiswa yang diajar secara wajar dan membantu mereka untuk keluar dari problematika yang dihadapi dalam belajar bahasa Arab, dan diharapkan dosen bisa menjadi teladan yang baik bagi para mahasiswanya. Sebaliknya, mahasiswa yang diajar harus juga menghargai peran penting dosen yang mengajar mereka dan memposisikan mereka sebagai orang tua dan fasilitator mereka dalam belajar bahasa dan memandu mereka mempelajari dan menguasai bahasa Arab dengan baik.

3. Dosen bahasa Arab harus sabar dalam mengajar mahasiswanya baik ketika dia mengajar didalam kelas maupun ketika berinteraksi di luar kelas, karena kesabaran dosen dalam mengajar akan berpengaruh besar dalam mengantarkan mahasiswa kepada keilmuan yang dipelajari di kampus, termasuk ketika mahasiswa menggunakan Bahasa Arab daam berkomunikasi dengan dosen yang kadang salah dalam memilih kosakata dan kalimat yang benar dalam berbicara. Sikap sabarnya dosen akan memberikan sugesti tersendiri bagi mahasiswa untuk berani bicara karena mahasiswa merasa terbantu dengan sikap sabarnya dosen ketika mereka bicara dengan dosen mereka.

4. Dosen bahasa Arab perlu berpartisipasi secara langsung bersama mahasiswa yang diajar dibeberapa kegiatan yang dilaksankan mahasiswa, baik kegiatan yang berhubungan dengan mata kuliah yang dipelajari di kelas, ataupun kegiatan yang dilakukan oleh mahasiswa melalui organisasi kemahasiswan mereka di kampus dan kegiatan berbahasa Arab luar kampus termasuk kegiatan sosial lainnya yang dilaksanakan.

5. Dosen bahasa Arab diharapkan bisa membarengi sikap seriusnya dalam mengajar di kelas dengan teknik yang beragam, dan tidak fokus dengan satu teknik yang sama saja, bahkan sangat disarankan jika dosen mau mengajar bahasa Arab dengan sedikit menggunakan humor untuk menghilangkan kekakuan yang terjadi, dan tentunya saat humor itu dibutuhkan untuk digunakan dalam pembelajaran yang dilaksanakan. Bentuk lain adalah dengan senyuman, dengan senyuman dosen kepada mahasiswa, kadang bisa memberikan sugesti khusus kapada mahasiswa yang diajar dan tergambar dari respon yang muncul dari wajah mahasiswa yang diberikan senyuman tersebut. Humor dan senyuman ini bisa menjadi alat untuk menghilangkan rasa takut yang muncul dari sebagian mahasiswa dalam belajar bahasa Arab yang dilaksanakan di kelas ataupun diluar kelas.

6. Dosen pengajar bahasa Arab diharapkan mau untuk mengalokasikan sedikit waktu yang dimiliki untuk berkenan bertemu dan bahkan melakukan perjalanan khusus dengan kelompok mahasiswa yang diajar untuk melaksanakan kegiatan akademik dan ilmiah lainnya di luar kampus sebagai bagian dalam membangun kedekatan dan keberanian mahasiswa untuk berinteraksi dan menggunakan bahasa Arab sebagai bahasa komunikasi yang digunakan dengan dosen dan mahasiswa lainnya.

\section{Hubungan Baik Dosen dengan Orangtua dan Keluarga Mahasiswa}

Dalam melakukan proses pembelajaran bahasa Arab, sudah seharusnya kampus tidak berdiri sendiri, tetapi bisa melibatkan para orangtua atau keluarga mahasiswa dalam mendukung proses 
pembelajaran bahasa Arab yang akan dilaksanakan. Di antara kegiatan yang bisa dilakukan adalah sebagai berikut:

1. Dosen bahasa Arab bisa membangun komunikasi yang lebih terbuka dengan orang tua ataupun keluarga mahasiswa, khususnya terkait dengan usaha melibatkan orang tua atau keluarga mahaisiswa dalam mendukung dan memfasilitasi pembelajararan yang dilaksanakan, baik di kampus maupun di rumah. Fasilitas yang diberikan bisa dalam bentuk fasilitas tempat belajar seperti ruang belajar khusus, suasana belajar yang diciptakan ataupun monitoring berjalannya proses belajar di rumah, melihat sejauh mana mahasiswa dipantau untuk mau belajar secara mandiri dirumah, mengerjakan tugas yang diberikan dosennya. Semakin kuat dan positif hubungan dosen dengan orang tua atau keluarga mahasiswa, maka akan lebih mudah untuk mencapai target dosen dalam mengajar mahasiswa.

2. Walaupun kedekatan dan komunikasi dengan orangtua dan keluarga mahasiswa sudah terjalin, diharapkan seorang dosen bahasa Arab tidak serta merta selalu harus menyampaikan hal-hal negatif yang muncul dari mahasiswa yang diajar kepada keluarganya. Dosen harus bisa memilih dan memilah kapan saatnya harus berkoordinasi dengan orangtua dan keluarga, kapan saatnya bisa mentolerir satu kesalahan kecil yang ada dan memaafkannya, kapan saatnya untuk mengingatkan mahasiswa untuk tidak mengulangi kesalahan yang sama, dan lain sebagainya.

3. Dengan hubungan baik yang terjalin dengan orangtua dan keluarga, dosen kemahiran berbahasa Arab diharapkan juga memotivasi mahasiswa untuk menjadikan kedekatan ini sebagai alat untuk sama-sama belajar dan ikut berpartisipasi positif dalam proses komunikasi antara dosen dan orangtua, khsusunya dalam hal pembelajaran bahasa Arab yang dilaksanakan.

4. Dosen bahasa Arab mendorong mahasiswa untuk menggunakan teknologi pendidikan yang digunakan di kampus dalam proses pembelajaran yang dilaksanakan dan membantu orang tua dan keluarga untuk ikut berpartisipasi dalam mendukung kegiatan yang dilaksanakan oleh kampus khususnya dalam pembelajaran Bahasa Arab dengan menggunakan beberapa media, alat bantu dan teknologi pembelajaran.

5. Dosen bahasa Arab diharapkan untuk selalu membangun komunikasi dengan orangtua dan keluarga mahasiswa, apapun hasil yang didapatkan oleh mahasiswa dalam menjalankan proses pembelajaran di kampus. Baik jika ada masalah ataupun tidak ada masalah, begitu juga ketika mahasiswa yang diajar kemampuannya meningkat sesuai target yang ingin dicapai ataupun ketika mahasiswa yang bersangkutan ada kendala dalam proses pembelajaran bahasa Arab yang dilaksanakan.

6. Jika dalam kondisi khusus sangat memungkinkan dosen bahasa Arab bisa bertemu ataupun mengundang secara khusus orang tua atau keluarga mahasiswa ke kampus atau ketemu ditempat tertentu menyepakati hal-hal yang bisa mendukung keberhasilan mahasiswa dalam belajar bahasa Arab di kampus.

7. Diharapkan para dosen bahasa Arab bisa bekerja sama dengan orang tua dan keluarga untuk menemukan solusi yang tepat dalam mengatasi masalah yang dikhawatirkan terjadi kepada mahasiswa yang diajar. Apapun masalah yang dihadapi baik oleh mahasiswa sendiri ataupun kampus tempat di mana mahasiswa itu kuliah untuk mencapai tujuan bersama dan mengatasi kesulitan mahasiswa dalam pembelajaran.

\section{Simpulan}

Dari pembahasan tersebut, dapat diambil simpulan bahwa para dosen yang mengajar kemahiran berahasa Arab di perguruan tinggi Indonesia, secara khusus di Universitas Al Azhar Indonesia secara umum sudah menggunakan metode yang tepat sesuai dengan karakter mata kuliah kemahiran berbahasa Arab yang diajarkan, tetapi secara hasil dalam bentuk penguasaan kemahiran berbahasa, 
kemampuan mahasiswa belum sesuai dengan tujuan yang diinginkan. Selain itu, banyak hal yang menyebabkan belum maksimalnya kemampuan mahasiswa dalam menguasai kemahiran berbahasa Arab dari hasil metodologi yang digunakan oleh dosen, yang salah satunya penyebabnya adalah kurangnya inovasi dalam pengembangan teknik mengajar berbasis metodologi yang dipilih dalam pembelajaran bahasa Arab. Di sisi lain, para dosen di perguruan tinggi Indonesia perlu untuk menurunkan metode yang telah dipilih ke dalam teknik mengajar yang inovatif agar memberikan dorongan lebih dan semangat bagi mahasiswa dalam belajar bahasa Arab. Di antara bentuk pengembangan teknik mengajar yang diusulkan penulis dalam artikel ini berhubungan dengan: sifat dosen yang dianggap sukses dalam pembelajaran bahasa Arab, keahlian yang harus dimiliki dosen, tips yang bisa dilakukan dalam menanamkan rasa cinta antara dosen dan mahasiswa dalam pembelajaran, dan aktivitas antara dosen dan keluarga mahasiswa yang bisa mendukung pembelajaran bahasa Arab yang bisa dilaksanakan, agar pembelajaran bahasa Arab yang dilaksanakan lebih menyenangkan.[]

\section{Daftar Rujukan}

Abdul Wahab, Muhbib., et al. 2018. "Standarisasi Kompetensi Bahasa Arab bagi Calon Sarjana Perguruan Tinggi Keagamaan Islam Negeri”, Arabiyat: Jurnal Pendidikan Bahasa Arab dan Kebahasaaraban, Vol. 5 No. 1.

al-Hudaibi, Ali Abdul Muhsin. 2008. 'Fa'āliyyah Barnāmij Qāim ala Ma’āyir Ta'līm al-Lughah alArabiyyah ka Lughatin Ajnabiyyah fi Tanmiyat al-Mahārat al-Hayātiyyah al-Lāzimah li anNāthīqina bi Lughat Ukhrā”, Thesis, Jami’ah Asyuth Kairo.

Bakhru, Kanupriya Misra. 2017. "Personal competencies for Effective teaching: A Review Based Study", Educational Quest- An International Journal of Education and Applied Social Sciences, Vol. 8.

Barakah, Zaid. 2003. "Metodologi Pengajaran Bahasa Arab", Diktat Kuliah di International Institute for Arabic Language, Khartoum, Sudan.

Effendy, Ahmad Fuad. 2012. Metodologi Pengajaran Bahasa Arab. Malang: Misykat.

Ginting, Abdurrahman. 2014. Esensi Praktis Belajar Pembelajaran. Bandung: Humaniora.

Hamalik, Oemar. 2013. Dasar-Dasar Pengembangan Kurikulum, Bandung: PT Remaja Rosdakarya.

Hermawan, Acep. 2011. Metodologi Pembelajaran Bahasa Arab. Bandung: Remaja Rosdakarya.

Ilyas, Alinis. 2018. "Dosen Bahasa Arab dan Kompetensinya dalam Mengaktualisasikan Teknik Pembelajaran Interaktif”, Jurnal Al-Bayan, Vol.10, No.1.

Muradi, Ahmad., dan Taufiqurrahman, Pengembangan Kurikulum Pembelajaran Bahasa Arab. Jakarta: PT. Raja Grafindo Persada, 2021.

Muradi, Ahmad. 2016. "Pengembangan Kompetensi Guru Bahasa Arab Melalui IMLA Sebagai Organisasi Profesi", Arabi: Journal of Arabic Studies, Vol. 1, No. 2.

Nasution, S. 2008. Kurikulum dan Pengajaran. Jakarta: Bumi Aksara.

Pengaturan Menteri Pendidikan Nasional Republik Indonesia No. 16 Tahun 2007 tentang Standar Kualifikasi Akademik dan Kompetensi Guru.

Permendiknas No. 42 Tahun 2007 tentang Sertifikasi Dosen.

Sanjaya, Wina. 2016. Strategi Pembelajaran Berorientasi Standar Proses Pendidikan. Jakarta: Kencana Prenada Media. 


\section{Arabi : Journal of Arabic Studies}

Sholeh, Nur., \& Ulin Nuha. Pengembangan Kurikulum Bahasa Arab. Yogyakarta: Diva Press, 2013.

Supartha, I Wayan Gede., et al. 2020. “Does teacher competence and commitment improve teacher's professionalism", Cogent Business \& Management, Vol. 7, No. 1.

Susanti, Susi., et al. 2020. "Pengaruh Kualifikasi Akademik dan Kinerja Guru Terhadap Nilai Siswa", Jurnal of Education Research, Vol. 1, No. 2.

Sutikno, Sobry. 2014. Metode \& Model-model Pembelajaran. Lombok: Holistica.

Thu'aimah, Rusydi Ahmad. 2001. Manāhij Tadrīs al-Lughah al-'Arabiyyah bi at-Ta'Tim al-Asāsî. Kairo: Dār al-Fikr al- Arabi.

UU No. 14 tahun 2005 tentang Guru dan Dosen.

Wardoyo, Cipto. 2015. “The Measurement of Teacher's Personality Competence and Performance Using Embedded Model”, Journal of Education and Practice, Vol. 6, No. 26.

Wibawa, Restu., et al. 2019. "Pengaruh Pembelajaran Practice Rehearsal Pada Mata Kuliah Media Tiga Dimensi terhadap Kreativitas Belajar Mahasiswa di Jurusan Teknologi Pendidikan”, Jurnal Teknologi Pendidikan, Vol. 4, No. 2. 